\title{
The Description of the Application of Healthy Workplaces at PT PJB Power Plant Unit Gresik
}

\section{Gambaran Penerapan Healthy Workplaces di PT PJB Unit Pembangkitan Gresik}

\author{
Dinda Ocvita Windi Pratiwi \\ Department of Healthy Promotion and Behavioural Science, Faculty of Public Health, Universitas Airlangga \\ Campus C Mulyorejo, Surabaya, East Java, 60115 Indonesia
}

\begin{abstract}
Introduction: Healthy workplaces is a concept where everyone in the work environment works together to achieve the vision of the health and welfare of workers and the surrounding community. PT PJB UP Gresik is a supplier of electrical energy since 14th June 1996, and has received top management awards in 2018 with zero accidents in 2018 and 2019. This study aimed to describe the working environment of PT PJB UP Gresik using Healthy Workplaces Theory. Methods: The study was conducted in February-August 2019 through descriptive of quantitative method. The population involved was 325 workers selected using simple random sampling, divided into two groups of 22 managements, and 76 staffs. Research tool used was in the form of WHO questionnaire. The study passed the ethical review of the Faculty of Dentistry, Universitas Airlangga in June 2019 number 324/HRECC.FODM/VI/2019. Result: As much as 97\% of the management and $76 \%$ of staff agreed that the company had health-oriented regulations. It also obtained that $100 \%$ management, and $92 \%$ staff agreed that the company's psychosocial environment was healthy. As much as $96 \%$ of each respondent group agreed that the work environment was safe. About 63\% management and $64 \%$ staff agreed that the company supported changes in healthy lifestyles. Around $60 \%$ management and $64 \%$ staff agreed that the company's health service units were available and implemented well. The statement of company being a good effect has been approved by $89 \%$ of the management. Conclusion: PT PJB UP Gresik has a healthy work environment and can be improved if it pays more attention to the lifestyle and the functions of health service.
\end{abstract}

Keywords: heat radiation, noise, ship production

\section{ABSTRAK}

Pendahuluan: Healthy workplaces adalah konsep semua orang di lingkungan kerja bekerjasama mencapai visi kesehatan dan kesejahteraan pekerja serta masyarakat sekitar. PT PJB UP Gresik merupakan perusahaan pemasok energi listrik wilayah Jawa-Bali sejak 14 Juni 1996, dan telah memperoleh penghargaan top management tahun 2018 serta zero accident tahun 2018 dan 2019. Penelitian ini bertujuan mendeskripsikan lingkungan kerja PT PJB UP Gresik menggunakan Teori Healthy Workplaces. Metode: Penelitian dilakukan pada Bulan Februari-Agustus 2019, bersifat deskriptif dengan metode kuantitatif. Populasi penelitian 325 pekerja, pemilihan subyek penelitian menggunakan teknik simple random sampling, dibagi menjadi dua kelompok, manajemen 22 orang, staf 76 orang. Alat penelitian berupa kuesioner WHO. Penelitian lulus kaji etik Fakultas Kedokteran Gigi Universitas Airlangga Bulan Juni 2019 dengan nomor 324/HRECC.FODM/ VI/2019. Hasil: Sebesar 97\% manajemen dan 76\% staf setuju perusahaan memiliki peraturan berwawasan kesehatan. Sebesar 100\% manajemen, dan 92\% staf setuju, lingkungan psikososial perusahaan sehat. Sebanyak 96\% masing-masing kelompok responden setuju bahwa lingkungan kerja aman. Sebesar 63\% manajemen dan 64\% staf setuju perusahaan mendukung perubahan gaya hidup sehat bagi pekerja. Sebesar 60\% manajemen dan 64\% staf setuju unit pelayanan kesehatan perusahaan telah tersedia dan berjalan baik. Perusahaan berdampak baik bagi sekitar telah disetujui oleh $89 \%$ manajemen. Simpulan: PT PJB UP Gresik memiliki lingkungan kerja yang sehat dan dapat disempurnakan apabila lebih memperhatikan komponen perubahan gaya hidup pekerja dan fungsi dari unit pelayanan kesehatan yang tersedia.

Kata kunci: tempat kerja sehat, lingkungan kerja, sehat

Corresponding Author:

Dinda Ocvita Windi Pratiwi

Email: Dindaocvita@gmail.com

Telephone: +6281230800583

\section{INTRODUCTION}

As time goes by in this millennial era, the definition of work environment becomes increasingly complex. Work environment which is considered as ideal for employees is no longer just about a 
comfortable work environment for workers, but it needs to pay more attention to the health status of workers. The organization is no longer focused solely on profit, now management's attention in the organization also focuses on the health of the workers. The organization is aware that workers' health is also an asset or a long-term investment that benefits them. A good work environment is not enough, a healthy work environment is needed to support workers so that their performance is more optimal.

Based on Omi (1999), a healthy work environment or referred to as healthy workplaces is a concept where all people in the work environment works together to achieve a mutually agreed vision of the health and welfare of workers and surrounding communities. A healthy work environment facilitates workers with physical, psychological, social and organizational conditions that can protect and promote health and safety principles at work. This allows managers and workers to increase control over their own health, and makes them more energetic, positive and satisfied in carrying out the tasks assigned to them. In return, the workforce is more stable, committed and productive, making it easier for the organization to achieve its desired goals.

There are six important factors that must be met by the organization in the effort to achieve a healthy work environment. Health care organization regulations of psychosocial work environment and physical work environment which are in accordance with the rules of occupational health and safety (OHS), a healthy workforce lifestyle, the availability of health service units in the work area and the effect of the organization are not only on the workforce but also on the environment around the organization. All of that that can be done with the support of health promotion that can be done by the organization. The principles that guide the development of a healthy environment must be comprehensive, participatory and empowering.

The practice of procuring a healthy work environment in Indonesia itself is still rarely practiced. This is proven by the number of work accidents in Indonesia amounting to 80,392 cases. Yet along with the implementation of healthy work environment procurement practices in organizations has an indirect advantage that can reduce the number of work accidents. In addition, looking at the way of most Indonesians' perspectives who are still illinformed is a proof that there are still many people do not understand the importance of maintaining their health status. This is the basis of researchers to conduct further research on the practice of procurement of a healthy work environment in Indonesian companies. The purpose of this study was to describe the work environment at PT PJB Gresik of Power Plant Unit using healthy workplaces theory. The descriptions of the work environment were carried out using the approach of the six components of Healthy Workplaces Theory.

\section{METHODS}

Based on the type of research and data collection method, this research was descriptive study where the researcher only describes the data that have been collected as it is without intending to make a conclusion or generalization. This analysis is only in the form of accumulation of basic data in the form of description in the sense of not seeking or explaining the relationship, testing the hypotheses, making predictions, or drawing conclusions. According to the place of the implementation, this research was field research. The current research used quantitative method, the available data are presented in the form of a frequency distribution of answers from the questionnaire which were then matched with the study of documents and observation as the supporting data.

The population in this study was the entire workforce of PT PJB UP Gresik in August 2019 totaling 373 workers, with details of the management section of 48 workers and the supporting staff section of 325 workers. The sampling in this study was carried out by simple random sampling. Each workforce had the same opportunity to be selected as the research sample (Notoatmodjo, 2002). The results of the sampling were categorized into two groups those are management group of 22 samples and supporting staff group of 76 samples.

The data collected were primary data and secondary data. The primary data used were the results of questionnaires, document studies and observations in the field. The research questionnaire use the Guttman scale and was divided into two types, for the management sample and for the staff sample. Meanwhile, the secondary data were obtained from the data in the company. The secondary data were obtained in the form of company history, a general description of the company, organizational structure, and policies that have been applied in the company related to 
the research theme. All data obtained were then analyzed using quantitative descriptive methods and are presented in the form of frequency distribution of questionnaire answers accompanied by supporting narratives. Based on the results of the analysis, it showed how the healthy workplaces theory has been implemented by PT PJB UP Gresik in the provision of a healthy work environment.

This study has passed the ethical test in the faculty of dentistry of Universitas Airlangga with ethical clearance certificate number 324/HRECC. FODM/VI/2019.

\section{RESULTS}

\section{Workplaces Policies}

In the questionnaire distributed to management respondents, there were ten types of statements that could illustrate the application of the company regulation component at PT PJB UP Gresik. Based on the frequency of the questionnaire answers from 22 samples, $97 \%$ of the answers were yes and $3 \%$ of the answers were no. For the questionnaire given to the staff, there were six statements answered yes by $76 \%$ and answered no by $24 \%$. After being analyzed using data from documentation studies, PT PJB UP Gresik has owned and implemented company regulations that were health-oriented in its work environment.

PT PJB Gresik of Power Plant Unit has placed occupational health and safety (OHS) as the main objective. This is in line with the management system policy document of PT Pembebunan JawaBali with document number 029.K/020/DIR/2018. In the management policy number five, it is written that the company has taken efforts in preventing and overcoming the potential environmental pollution, work accidents and work-related diseases by paying attention to the aspects of the environmental effect and being responsible for the community empowerment by being actively involved in taking roles and social responsibility for the effect of corporate decisions and transparent and ethical activities.

In order to support the vision, mission and policies of the company's management system, PT PJB Gresik of Power Plant Unit formed a team of Work Safety Guidance Committee (P2K3). The establishment of P2K3 aims to create safe, healthy, clean and productive working environment conditions as an effective means of preventing accidents, occupational diseases and damage to company assets, by conducting active and innovative monitoring efforts. The P2K3 team was formed by involving all workers in the company regardless of certain sections or positions. The formation of $\mathrm{P} 2 \mathrm{~K} 3$ team is regulated in the decree of the general manager of PT PJB Gresik of Power Plant Unit Number 025.K/020/UPGRK/2019.

The P2K3 team is responsible for maintaining occupational health and safety in the field, not only in work attitudes but also in work areas such as buildings, production machinery, and potential hazards that can arise during work activities. The form of responsibility is to carry out planned monitoring. Monitoring is done through direct patrols to the field and filling out some survey sheets that have been provided. All data generated will then be managed by the P2K3 team as the company's K3 data bank. All P2K3 team activities are arranged in a systematic work plan that contains a routine schedule of monitoring and presentation of results to the management once every month.

In addition to emphasizing health and safety in the work area, WHO also demands companies to make recruitment and dismissal of workers on the basis of applicable and fair rules. The new recruitment system is regulated in the PJB-IMS (PJB Integrated Management System) where the responsibility for opening vacancies is held by PT PLN as the central company. Whereas, the dismissal of workers is based on the directors' decision documents of PT. Java Bali Power Plant No 113.K/010/DIR/2010 concerning disciplinary regulations for the employees of PT Jawa-Bali Power Plant. This regulation regulates the disciplinary actions of the company. Starting from the elaboration of the rules, the types of violations are categorized into 3 types those are mild, moderate, to severe, in addition to sanctions which are given according to the type of violation committed.

For workers who want to get information about K3 in the company, PT PJB UP Gresik has prepared a special information channel named $5 \mathrm{~S}$ information board. The $5 \mathrm{~S}$ information board contains static information and dynamic information. Static information is information that is permanent such as management policies, guidelines for using uniforms, emergency call numbers and extension numbers for each field contained in PT. PJB UP Gresik. Meanwhile, the dynamic information contains information that can be updated regularly, such as the standby picket schedule, monthly schedule 
for each shift of the production unit, audit results, management patrol and meeting results. The $5 \mathrm{~S}$ information board can be found in every operating unit and room of every field in the company.

\section{The Psychosocial Work Environment}

In the questionnaire distributed to 22 management respondents, there were five statements regarding the application of psychosocial work environment factors in PT PJB UP Gresik, with a $100 \%$ yes answer frequency. Meanwhile, the questionnaire which was distributed to 76 supporting staff respondents had eight types of statements, with a frequency of $92 \%$ yes answers and $8 \%$ of no answers. The next results were analyzed with the existing documentation studies so that it can be considered that PT PJB UP Gresik has tried to create and maintain a supportive psychosocial work environment for the workforce.

A comfortable and supportive psychosocial work environment is formed by arranging work hours that do not burden and cause excessive stress for the workforce. The current standard is the ILO in 1952. The ILO Standard is 8 hours of work per day or 40 hours of work per week for 5 working days within 1 week with a rest period of at least half an hour after working for 4 hours continuously. When compared with working hours at PT. PJB UP Gresik as stated in the directors' decision document of PT. Java-Bali Power Plant Number 057.K/010/ DIR/2015 concerning changes to the employee's work entry conditions, the working hours are already appropriate.

PT PJB Gresik of Power Plant Unit facilitates workers with clear job descriptions in every position and field in the company. This is done to avoid overlapping duties and obligations. In carrying out the duties and obligations, each individual worker is given a target and deadlines that are realistic and do not burden in order to minimize stress that can be experienced by workers. The company also provides an opportunity for every employee to be able to take part in the existing decision making process. This process is usually carried out during deliberations or voting in the last session of the meeting or in a special session called the kick-off meeting session.

The company's management system uses PJBIMS (Integrated Management System) management system. PJB-IMS regulates various management activities that occur in the company environment such as the process of employee placement. This process is carried out by giving equal opportunities to each employee to obtain the desired fields and promotions according to their competencies. In addition, PJB-IMS also regulates the awarding and sanctions for workers. This is done to provide a psychological deterrent effect for the workforce concerned. PJB-IMS does not only regulate workers who are still active, but also workers who will retire. It was done through training of entrepreneurship and provision of support in the form of severance pay paid once and the pension paid every month by the company.

Another effort taken by PT PJB Gresik of Power Plant Unit to improve the psychosocial work environment conditions owned is by creating an employee gathering program. The employee gathering program aims to strengthen the workforce relations, cooperation as well as a means of recreation and entertainment for workers. This program is filled with outbound activities designed in such a way with the theme of cooperation and leadership. This program is conducted outside the city and is carried out routinely once a year.

\section{The Physical Environment}

In the questionnaire distributed to 22 management respondents, there were twenty-one statements regarding the application of physical work environment factors in PT PJB UP Gresik, with a frequency of $96 \%$ yes an-swers and $4 \%$ no answers. For the questionnaire distributed to 76 supporting staff respondents, there were seventeen types of statements, with a frequency of $96 \%$ yes answers and $4 \%$ no answers. The next result was analyzed using the existing documentation study so that it can be con-sidered that PT PJB UP Gresik tried to create and maintain a healthy and safe physical working environment to use.

PT PJB Gresik of Power Plant Unit in designing workplaces always considers occupational health and safety as the main thing. Even though they have built a physical work environment that is in accordance with OHS principles, it still does not eliminate the existence of a patrol program or inspection to the field, especially the production unit to control various components, both equipment and work environment that have potential hazards or can reduce the comfort level of staff when working. PT PJB UP Gresik also facilitates the workers with health and safety signs in all work areas. The purpose of installing signs is to be able to educate workers and minimize workplace accidents by giving warning in advance. 
In order to maintain the security and safety of workers, PT. PJB UP Gresik has a protocol regarding the state of emergency response in the work area that must be understood by every worker. The intended emergency response conditions included, but are not limited to fires, natural disasters, terrorism and equipment failures that have an effect on the sustainability of the production process. The emergency response protocol is written in the work instructions No. IKG-08.2.4.1

In the event of fire, the company has a special program which is fire protection in the work area. The fire protection effort is by forming a special team for handling fire emergencies consisting of every field in the company. This special team is called the Fire Rescue Team. The structure, duties and responsibilities of the Fire Rescue Team are set out in PT PJB UP Gresik general manager's decision document No. 002.K/020/UPGRK/2020 concerning Demonstration of PT PJB Fire Rescue Team Gresik of Power Plant Unit.

PT PJB Gresik of Power Plant Unit also has a HIRARC system to assist workers in carrying out daily work activities. HIRARC contains guidelines for the use of tools and machines developed in the form of manuals (available in both online and offline forms) and working procedures that are useful for looking at the effect caused by technology or new work systems that are applied to the health and safety of workers.

At work, the company gives special rights for every worker to refuse employment if it is considered unsafe or does not meet occupational health and safety standards. In the production unit, it can be in the form of refusing to work when it is raining and refusing to work if the PPE provided is inadequate. However, this is followed by the company's right to stop unsafe work, or if the worker has an unsafe working attitude. This termination is done by intermediary ticketing, or termination of direct work done by the OHS Sector.

In the front of the work area, there is a special place for workers who want to rest and have lunch in the form of a company canteen. The canteen provides healthy and nutritious food and drinks for the workforce. Right across the canteen, the company also provides a place of worship in the form of a mosque that can be used not only for workers but also the surrounding community.

PT PJB Gresik of Power Plant Unit also pays attention to the sanitary conditions of its workforce, by providing adequate toilets, both for male and female toilets. Toilets are available on everin each $y$ floor of the company building. The toilets are always clean, equipped with adequate water, a sink, and adequate sanitary equipment such as tissue, soap and trash bin.

In addition to the problem of toilet availability, another concern in worker sanitation is the regularly cleaned work area. PT PJB UP Gresik itself has provided a cleaning service team that is spread in every point of the company. However, to foster a caring attitude about cleanliness, PT PJB UP Gresik also applies a picket system for the production unit in cleaning the work environment and for each nonoperators staff is given the responsibility to maintain the cleanliness of the area around his work desk. The waste disposal system is also well organized, sorted into organic and inorganic waste so that it is easy to be processed again. In addition, it is also in accordance with applicable health standards.

\section{Lifestyles and Personal Health Skills}

In the questionnaire distributed to 22 management respondents, there were eleven statements regarding the application of the workers lifestyle factors in PT PJB UP Gresik environment, with a frequency of yes answers by $63 \%$ and no answers by $37 \%$. For the questionnaire distributed to 76 support staff respondents, there were nine types of statements, with a frequency of yes answers by $64 \%$ and no answers by $36 \%$. The next result was analyzed with the existing documentation study so that it can be considered that PT PJB Gresik of Power Plant Unit has supported its workforce to be able to change into a healthier lifestyle.

PT PJB Gresik of Power Plant Unit conducts a healthy lifestyle training in the form of a routine morning gymnastics program which is carried out every Friday. The exercise material that is presented is designed to be interesting, with the latest rhythm or music, and to meet the needs of the workforce as a whole (aerobics, muscle stretching). To attract the attention and desire of workers to participate in the gymnastics activities and also as a form of appreciation for the company, extra food and in the form of electrolyte drinks and light snacks are always distributed.

As another effort to improve the quality of workers' life style, PT PJB Gresik of Power Plant Unit provides supporting facilities for workers who want to do physical exercise. The facilities provided are in the form of multipurpose sports fields, badminton and volleyball courts, sports buildings 
that can be accessed and utilized by all workers and even the community surrounding the company. The work environment also provides paddle bikes for workers who want to use it for physical ac-tivities.

To improve the quality of workers' lifestyle to be healthier, PT PJB UP Gresik created a program that utilizes health promotion media in the form of audio that is played every day at exactly 10:00 am. The audio played throughout the PT PJB UP Gresik's working area contains an invitation for workers to do a momentary stretching with correct procedures. Through this, it is expected to minimize work-related stress and work-related illnesses.

PT PJB UP Gresik does not only pay attention to its workforce and work environment, but also the environment around the company. The form of attention given by PT PJB UP Gresik is by supporting events on health promotion in the surrounding environment as a sponsor. Support provided can be in the form of material (money) or competent speakers.

\section{Health Services}

In the questionnaire distributed to 22 management respondents, there were five statements regarding the application of health service factors to PT PJB UP Gresik environment, with a frequency of $60 \%$ yes answers and $40 \%$ no answers. For the questionnaire distributed to 76 support staff respondents, there were six statements, with a frequency of yes answers of $64 \%$ and no answers of $36 \%$. The next result was analyzed using the existing documentation study so that it can be considered that PT PJB Gresik of Power Plant Unit already has a health service unit in its work environment.

PT PJB Gresik of Power Plant Unit provides health care clinics within the company. It is precisely located in the front right and next to the mosque. The company clinic was created to provide a basic pre-employment medical examination as a means of assessing the worker's fitness and health level. The results of the pre-employment medical examination are used in establishing the basis for any periodic testing required.

The clinic also has the duty to provide basic medical examinations such as examinations which include vision, hearing, and blood pressure. Although further and complex medical examinations cannot be done in the clinic, the clinic doctors can provide referrals to more complete health service units or hospitals. The medical record of every worker recorded in the company's clinic will be fully the right of the company while maintaining the privacy of the workplace by not disseminating the contents of the medical record to other parties.

Since the workforces' health is the most important thing to support company productivity, so the clinic doctor of PT PJB Gresik of Power Plant Unit actively ensures that every worker has been immunized. The main target of clinic doctors is workers who have previously contracted with disease. As an example, there are workers who suffer from influenza, so after treatment and recovery, the clinic doctor will make sure that the worker carries out influenza immunization so that he does not experience it again. Other treatments that clinic doctors provide are in the form of giving vitamins to each worker as needed so that endurance is maintained and their health are always excellent. With this, it is expected that there will be no outbreaks of certain diseases which can disrupt the work activities at PT PJB UP Gresik.

\section{The Effect on External Environment}

In the questionnaire distributed to 22 management respondents, there were nine statements regarding the application of organizational effect factors on PT PJB UP Gresik environment, with a frequency of yes answers by $89 \%$ and no answers by $11 \%$. The next result was analyzed with the existing documentation study so that it can be considered that PT PJB Gresik of Power Plant Unit already has a health service unit in its work environment.

PT PJB Gresik of Power Plant Unit is committed to maintain the health of the environment around the company. This effort is carried out by complying with Environmental Management Standards or SML, as a form of environmental protection efforts undertaken. PT PJB UP Gresik also has an ongoing monitoring and supervision mechanism in the form of air sampling, emissions and pollution checks to monitor the environmental conditions that may be disrupted due to the company's production process.

The process of production work requires various materials that may have potential hazards. In the process of using material that has potential hazards, PT PJB UP Gresik is required to fill out the Material Safety Data Sheet or MSDS form to see how the handling should be, starting from packing at the time of purchase, delivery, use, and disposal. It is expected that by filling the MSDS, it can reduce the environmental effect that may occur. Various efforts to maintain environmental health are regulated by the environmental sector of PT PJB UP Gresik. The 
results of all environmental tests and the effects must be reported to the government and the community. This reporting system is called Environmental Effect Aspect Identification Program or abbreviated as IADL.

Another commitment made by PT PJB Gresik of Power Plant Unit in maintaining sustainability and efforts to develop the surrounding environment is by providing resource facilities that have cleanliness and beauty value. One example is the existence of a program to procure trash and ornamental plants for people who live around the company as a form of company cares about cleanliness and environmental sustainability.

\section{DISCUSSION}

\section{Workplaces Policies}

An organization which needs a healthy workplace must adopt health, safety and legal regulations and standards as its top priority. The organization has the right to develop regulations that comply with the requirements in their respective work environments. The organization should not be forget either that they are still responsible for the approval of all rules and standards enforced. Many organizations have agreed on the need for a workplace health policy intended to demonstrate their commitment to their work health and safety.

Laws, regulations and standards that apply in organizations can always be written and documented in a language that is clear and easy to understand. This can help the organization to minimize work errors. In addition, in written form, it can emphasize more about who decides and determines the roles and responsibilities related to implementation.

The application of laws, regulations and standards governing the occupational health and safety aims to improve the workforce performance and productivity. It will facilitate the organization to achieve the desired goals. This condition is a form of mutually beneficial relations both for workers and for companies. This is supported by previous research on occupational health and safety that is positive and significant for employee performance and productivity (Putri, 2017). The most important $\mathrm{OSH}$ indicator is occupational health and safety regulations.

\section{The Psychosocial Work Environment}

The organizational environment refers to organizational culture and how work is designed and organized. The elements of a healthy organizational environment include good leadership, open management style, increased employee participation, a sense of control over one's work, improved communication and teamwork, opportunities for professional and social development, protection from harassment and discrimination, a fair remuneration system, and other mechanisms for recognizing and rewarding good work.

According to Melur (2019), work environment has a significant positive effect on workforce performance and productivity. A work environment that provides training and opportunities to develop workforce careers can have a direct and indirect effect on the resulting performance. The direct effect that results is in the form of increased enthusiasm and satisfaction of workforce for the work done. Indirect effects are felt by companies that make it easier to achieve the desired targets and goals.

Organizational factors are known to have important influences on mental and physical health, especially stress-related conditions such as hypertension, coronary heart disease, and various emotional problems. Evidence shows that a workplace culture that cares, which encourages empowerment, skills development and accountability, and which encourages worker participation in decision making, has a positive effect on workers' health. The structure and sequence of work assignments are also important determinants of health. Work factors such as the type and variety of work tasks, workloads, repetitive movements, speed of work activities and work shifts can have a tremendous effect on employees' welfare.

According to Hastutiningsih (2019), workload has a significant influence on the incidence of stress due to work felt by work-force. Furthermore, work stress also has a significant effect on the resulting performance. Therefore, it is important for an organization to be able to create a healthy and comfortable psychosocial work environment for the workforce. A supportive psychosocial work environment can be in the form of providing realistic targets and deadlines during work, making the workforce can do activities comfortably and minimizing the work stress.

\section{The Physical Environment}

According to Handayani (2018), the design of the physical work environment and the regulation of temperature, noise, vibration, lighting, and air circulation have a partial effect on work productivity. Whereas the performance of workers has a 
simultaneous effect. Physical working environment conditions are important factors in the work process. If the physical work environment is designed according to K3 standards, the workforce will work more comfortably and feel that the work done is safe and not worrying. The perceived effect of the organization is that the productivity increases so that profits and goals are easily achieved.

A healthy workplace applies policies, programs and activities to eliminate or minimize exposure to physical, chemical, biological, psychosocial and ergonomic hazards in the work environment. Precautions must comply with the principle of "hirarcy of control", which prioritizes efforts to eliminate or reduce the source of danger. Engineering controls prevent work exposure by managing the work environment. Source of reduction measures include modifying processes or equipment that create hazards, replacing materials with less toxic alternatives, and better maintenance of equipment.

When source modification is not sufficient to achieve the desired level of control, hazards must be prevented through administrative controls, such as isolating work processes by placing equipment or chemicals in separate rooms or areas, better cleaning, or applying rotating systems so that an individual worker is not exposed to danger for a long time. As a last resort, occupational exposure can be avoided or reduced by placing protective barriers on workers, which is by using personal protective equipment, including safety helmets, safety shoes, respirators, gloves and eye protection. The use of personal protective equipment (PPE) is considered to have a relationship with workforce productivity, because it can increase the sense of security for the workforce at work (Hidayati, 2016).

One thing that is lacking in PT PJB Gresik of Power Plant Unit is not having a stress reduction management program for the workers. Reviewed from previous research, there are various ways to manage stress in the work environment. One of them is by holding a psycho-educational seminar. Based on the previous research, it is believed to reduce total workforce stress level by $64.2 \%$ and by $45.6 \%$ if this program is conducted at least once a month (Montero-marin et al., 2020).

\section{Lifestyles and Personal Health Skills}

Healthy workplace theory explains that improving working environment conditions must go hand in hand with support for lifestyle changes to be healthier. One of the efforts the organization can make is by providing health information and education, promotion of a conducive and healthy lifestyle and the development of personal health skills for each workforce.

Based on the previous research, by implementing healthy lifestyles in each workforce, it can be an alternative solution as a mechanism to reduce stressor when workers do certain jobs (Diy, Gratia and Septiani, 2014). The application of a healthy lifestyle has been shown to have a positive relationship with employee satisfaction and performance. When reviewed further, when each workforce has a healthy lifestyle, it can increase their daily work stamina and power. Therefore, the organization benefits in many ways including the decrease in pain compensation costs incurred and stable work productivity.

Similar result has appearred on newest study in United Kingdom. The application of a healthy lifestyle with full of organization support has been shown to have a positive relationship with employee well-being and their health status (Stanulewicz et al., 2020).

\section{Health Services}

The health service component in the healthy workplaces theory ensures that workers have access to basic, primary and preventive healthcare services, in addition to the health service unit which is located in the work area. Many large and medium-sized organizations provide on-site health services, while small businesses often rely on industrial clinics or community health centers. Contracts with health insurance providers support the provision of good health services.

The availability of health service units in the work area can facilitate the organization in handling critical situations in the event of occupational accident or illness. Health service unit can also assist the organization in organizing regulations and standards applied in the organization. This is also consistent with the results of previous research (Sari, 2010) stating that by having a health care unit, the organization is considered to have made efforts to improve the health and productivity of the workforce. In her research, it was stated that the provision of health service units, health checks (initial, periodic and special), and first aid for workers must not only be availa-ble during accidents, but it must also be easily accessed by workers in need. 


\section{The Effect on the External Environment}

The component of organizational effect is not only isolated in the work environment but also the external environment. A healthy work environment can seek to prevent external pollution by considering the health and environmental effects of raw materials, production processes, energy consumption, waste generation, product distribution and use, and product recycling. The purpose of "clean production" is to avoid producing pollution rather than focusing on what to do with waste and emissions once they are created. Organizations have a key role in environmental preservation. This is in accordance with a journal stating that it is a corporate social responsibility to integrate social and environmental concerns in business operations and voluntary interaction with stakeholders to empower the community and to keep the company's operations running smoothly without disruption (Tuju, 2016).

Not only the negative effects produced by organizations, the presence of certain companies in the community environment can indirectly improve the economy. This is because the emergence of several business opportunities that are considered by the community to be beneficial. Even the existence of a company can cause a profound transition of professions (Edwandar, 2017).

\section{CONCLUSION}

PT PJB Gresik of Power Plant Unit has applied healthy workplaces theory to its work environment well. This is evidenced by the application of regulations in the work environment. Comfortable psychosocial environment conditions and the relationship of each employee is well established. The company also has a physical work environment that meets OHS rules and can provide a sense of security to workers who use it in their daily work activities.

PT PJB UP Gresik has also provided support to each workforce to be able to change their style and quality of life to be healthier. Another effort to maintain the health condition of the workforce is by providing basic health service units that are easily accessible. PT PJB UP Gresik is also committed to maintain the health of the surrounding environment by conducting a clean production process.

\section{ACKNOWLEDGEMENT}

I would like to show my gratitude to Idrus Pamungkas, as K3 supervisor in PT PJB UP Gresik, for his expert advice and encouragement during this research. I also would like to thank the reviewers' insightful review on the paper, as these comments led us to improve this work. This research is far from perfect, but it is expected to be useful not only for the research but also for the readers. For this reason, constructive and thoughtful suggestion and critics are wel-comed.

\section{REFERENCE}

Gratia, A. A. and Septiani, A. (2014) 'Pengaruh Gaya Hidup Sehat Terhadap Psychological WellBeing dan Dampaknya Pada Auditor KAP (Studi Empiris pada Auditor Kantor Akuntan Publik di Jawa Tengah Dan DIY)', Diponegoro Journal of Accounting, 3(2), pp. 1-12.

Edwandar, B. (2017) 'Pengaruh Keberadaan Perusahaan Terhadap Kondisi Sosial Ekonomi Masyarakat Desa Pangke Barat Kabupaten Karimun', JOM FISIP, 4(2), pp. 1-15.

Handayani, W. N. (2018) 'Pengaruh Lingkungan Kerja Fisik Terhadap Produktivitas Kerja Karyawan Operator Bagian Produksipada Perusahaan Manufaktur di PT ABAC Batam', Jurnal Aplikasi Administrasi, 21(1), pp. 9-30.

Hastutiningsih, A. T. (2019) 'Pengaruh Beban Kerja dan Lingkungan Kerja terhadap Kinerja Karyawan Dimediasi Stres Kerja', Prosiding National Conferenceon Applied Business, pp. $1-8$

Hidayati, D. (2016) Hubungan Antara Pemakaian Alat Pelindung Diri (Apd) Dengan Produktivitas Kerja Pada Pekerja Bagian Welding di PT Barata Indonesia (Persero) Cabang Tegal. Undergradutae Thesis. Semarang: Faculrty of Sport Science, Universitas Negeri Semarang.

Melur, R. (2019) 'Pengaruh Lingkungan Kerja, Diklat, dan Pengembangan Karir Terhadap Kepuasan Kerja Implikasinya Terhadap Kinerja Pegawai Di RSU Bireuen Medical Center', Jurnal Kebangsaan, 8(16), pp. 10-22.

Montero-marin, J. et al. (2020) 'Feasibility and effectiveness of a workplace-adapted mindfulnessbased programme to reduce stress in workers at a private sector logistics company: An exploratory mixed methods study', International Journal of Environmental Research and Public Health, 17(5), pp. 1-24.

Notoatmodjo, S. (2002) Metodologi Penelitian Kesehatan. Jakarta: Rineka Cipta.

Nutt, C. (2017) 'A Healthy Workplace', Midwives, 20(2), pp. 77-78. 
Omi, S. (1999) 'Regional Guidelines for the Development of Healthy Workplaces', Western Pacific: World Health Organization.

Putri, I. D. (2017) Pengaruh Pelaksanaan Kesehatan dan Keselamatan Kerja (K3) Terhadap Kinerja Karyawan PT. Bukit Asam (Persero) TbkUnit Pelabuhan Tarahan. Undergraduate Thesis. Lampung: Faculty of Economics and Business, Universitas Lampung.

Sari, M. P. P. (2010) Penerapan Pelayanan Kesehatan Kerja Bagi Tenaga Kerja di PT Menara Terus Makmur Cikarang Bekasi. Universitas Sebelas Maret. Undergraduate Thesis. Surakarta: Faculty of Medicine, Universitas Sebelas Maret.
Stanulewicz, N. et al. (2020) 'Effectiveness of lifestyle health promotion interventions for nurses: A systematic review', International Journal of Environmental Research and Public Health, pp. 17.

Tuju, C. (2016) 'Tanggung Jawab Perusahaan Dalam Konservasi Lingkungan Berdasarkan Undang-Undang Nomor 25 Tahun 2007 Tentang Penanaman Modal', Lex Crimen, 5(6), pp. 147-154. 